\title{
Education and the Division of Household Labor in Dual-Earner Families
}

\author{
ANNELI MIETTINEN \\ Researcher \\ The Population Research Institute, \\ The Family Federation of Finland
}

\begin{abstract}
This article is the first report of a study on policies and the division of paid and unpaid work in families in Finland. The article examines the division of household labor and its determinants in Finnish dual-earner families. The main objective is to examine whether education has any impact on the division of unpaid work and men's participation in it controlling for other variables. It was found, that among women, rising educational levels, non-traditional attitudes and younger age cohort had a negative impact on time spent on housework, while among men only reduced time in employment and nontraditional attitudes increased the contribution at home. While both men and women with higher education and non-traditional attitudes were more likely to perceive their relative division as more equal, an analysis of the absolute number of hours spent on housework seems to support the notion that more equal distribution of tasks at home is more or less a result of younger and educated women doing less housework. The data comes from a survey conducted in 1998, in which 2,500 Finnish men and women were questioned about time use, employment, attitudes about gender roles, work and family, and reconciliation of work and family. The Finnish study is part of a European research project which studies the division of labor in families in different cultural, political and societal settings.
\end{abstract}

Keywords: housework, education, dual income family

\section{Introduction}

In Finland women form almost half of the labor force, and the labor force participation rate among married women is among the highest in Europe. Although the double bread- 
winner model is well established in families, and women's income is increasingly needed to maintain the living standards of the families, women still continue to perform the majority of the household and child-care tasks while men provide a helping hand. Compared with past decades, women are spending less time on household tasks while men have increased their contribution somewhat, but changes in the distribution of unpaid labor within families have been small.

Increasing participation in paid labor and small changes in the distribution of unpaid work have meant that especially women's total work load has increased. Dual-earner families, especially those with children, feel questions concerning the distribution of housework most acutely. The reconciliation of work and family affects both men and women in these families. Changes in working life, such as flexible working hours, pressures to work overtime, part-time working and temporary employment contracts affect increasingly the organization of daily life. The division of household tasks is also an important source of distress in unions. It is found to affect marital satisfaction (Piña \& Bengtson 1993) and cause conflicts and disagreements between partners (Reuna 1998; Blair 1993; Kluwer et al. 1996).

It seems that Finnish men spend a little more time on household tasks than men in Central or Southern European countries (Jacobs 2000; Miettinen 1997). Due to different measurement techniques the differences in time used for housework among men are not definitive. What is clear, though, is that in all countries women tend to contribute 2-3 times the amount men do. During the past decades, women's labor force participation has increased steadily in all countries and women are more educated than before, and often better educated than men. Family structure is changing: the average number of children in families has declined and the number of people living alone is increasing. It is often expected that younger generations with more education and, perhaps, more individualistic life styles, are able to negotiate family roles more freely. The general ideological climate supports working women, and equality, not only in workplaces but also in the family. Why, then, in spite of these substantial changes affecting family life, have familial division of work and men's participation in household chores been so resistant to change?

When time use data from Finnish families from 1979 and from 1987/88 were compared, the division of housework between men and women had become more equal in all types of families during the intervening ten years. Men participated more in all families and women's contribution had decreased in families with $0-2$ children. In spite of the change, men continued to do less than two-thirds of the work women did even in families without children in which the distribution was the most equal (Niemi \& Pääkkönen 1989). Similar trends can be observed from studies using relative measures (Haavio-Mannila et al. 1984; Melkas 1998). Yet, relatively little is known of the factors which contribute to the division of housework at the family level in Finland. There may 
exist important differences in the values concerning family and work, and in the lifestyle preferences between social classes, or persons from different educational backgrounds, which affect, for example, men's participation in household chores. The objective of this article is to examine the division of housework and its determinants in Finnish dual-earner families using recent data, and more specifically, to test the hypothesis that an increased level of education will positively affect the sharing of household duties.

\section{Theoretical background}

In general, there are three theoretical approaches which are commonly used to explain the division of labor in families and men's participation in unpaid work. These include relative resources, time availability and gender role theories. In the relative resources approach the focus is on the power relation between partners (relative power in household decision making, as first described by Blood \& Wolfe 1960). Household work is seen as something unpleasant which both partners try to avoid. Both parties are using their relative resources to bargain a reduced share of chores. Earnings, occupational status, educational status, or relative measures of these variables, are used as indicators of power differentials within a relationship.

New home economics theory resembles the relative resources approach in that it also focuses on the relative resources each partner brings into the relationship. Resources are not considered as expressions of relative power to be used in a bargaining process, but as indicators of comparative advantage in the market or in the household. According to the new home economics approach, in order to maximize household utility function partners will allocate their time between paid and unpaid labor according to the marginal utility derived from employment and housework (Becker 1993). A partner with a comparative advantage in the market will specialize or allocate more time in the market, and a partner with a comparative advantage in the household will specialize in household work. Relative earnings are often used as an indicator of differences in the comparative advantage in the market. Thus, the theory assumes, the smaller the relative advantage (or earnings gap between partners) a man has in the market, the more time his wife will allocate to the market and the more time he will use for housework.

Studies of the impact of earnings have produced relatively consistent results: the smaller the gap between partners' earnings, the more equal is the division of housework (for example, Farkas 1976; Kamo 1988; Blair \& Lichter 1991; Presser 1994). Other studies using occupational status or educational level to measure relative power have been less consistent in their results, which can partly be due to different operationalizations of the variables in question (see Shelton \& John 1996, for the overview of studies using various measures of relative power). 
The time availability approach, on the other hand, focuses on the supply and demand sides of housework (demand/response capability, by Coverman 1985, or work status, by Kamo 1988). In every household there is a certain amount of housework that needs to be done, and distribution of the tasks among household members is determined according to who has the most available time to do the work. Employment reduces possibilities to contribute to household work, and creates pressures for others to "fill in the gap'. On the supply side, differences in the absolute hours in employment, or employment status, as well as in the flexible working hours between the couple, are used to explain differences in the division of labor. On the demand side, number of children is generally used to indicate pressure to increase time spent on household work. Most studies find that employment decreases both men's and women's contribution to household labor, but the relationship between women's employment and men's participation in housework is not clear (for example, Ross 1987; Kamo 1988; Blair \& Lichter 1991; also Künzler 1996, for the overview of studies which have used employment or hours in employment as an independent variable). Available time has also been operationalized as partners' overlapping hours in employment to better capture 'real' available time. In fact, in her study Presser (1994) found that the number of hours husbands were not employed while their partners were working did predict husbands' participation in "feminine" tasks.

The third approach, or gender role theory, explains the division of labor by differences in gender role attitudes. The theory assumes that men and women are socialized early in childhood or during adolescent years to appropriate gender behavior and thus later in their life express gendered personalities and preferences. According to theory, a person with more egalitarian, or liberal, non-traditional attitudes about gender roles will divide household tasks more equally (Stafford et al. 1977). Although a number of studies have found support for this hypothesis, the results are not always consistent, probably caused partly by variation in measures of sex-role orientation or normative attitudes about gender behavior (for example, Kamo 1988; Brayfield 1992; Presser 1994; see also Shelton \& John 1996, and Künzler 1996, for the overview of studies using gender role attitudes to explain division of housework). From 1990s on, a gender constructionist perspective has gained more attention. It emerged as a critique of rational choice theories on household labor (Berk 1985; Ferree 1990 and 1991). It tries to understand household workings from a gender construction perspective, where gender, like other products, is produced. Performing certain household tasks provides an opportunity to behave according to as appropriate sex category, or 'do gender', to prove that one is a member of a sex category. The gender constructionist perspective has been used mainly in qualitative studies on household labor, and so far, only a few studies which have tried to explain the division of household tasks or men's time spent on housework have included it in the analysis (for example, South \& Spitze 1994; Twiggs et al. 1999). The need to move beyond rationalistic explanations of the allocation of household labor and to better understand its social and cultural embeddedness are evident in recent research 
into the division of household labor and how it is linked to, for example, culturally different understandings of care work, kin relations, life course and family interaction factors (see Coltrane 2000, for an extensive overview of research into household labor during the 1990s).

Depending on the theoretical point of view, educational level has been used to measure relative power in a relationship, or differences in subcultural attitudes and life-style preferences. Its effect on housework behavior has thus been sometimes difficult to interpret. Many studies have found a positive association between men's educational level and their participation in household work (Farkas 1976; Rexroat \& Shehan 1987; Ross 1987; Kamo 1988; Brines 1994; Presser 1994; South \& Spitze 1994), and a negative association between education and time used on household tasks among women (Rexroat \& Shehan 1987; Bergen 1991; Brines 1994; South \& Spitze 1994). In another study, the effect of education was found to be negative also among men (Coverman 1985). In fact, in many cases, highly educated women reduced their contribution, thus creating a more equal distribution of household tasks, while highly educated men increased their contribution only a little or not at all. Yet, other studies have shown that education has no relation to participation in household tasks among women (Ross 1987), or neither among men nor women (Barnett \& Baruch 1987). Farkas (1976) and Presser (1994) have also studied the effect of relative education on the husbands' participation in housework. Contrary to the relative resources hypothesis, relative educational level did not have any significant effect on the division of housework in either of these studies.

It is possible that education captures life-style preferences or values which are not measured by common sex role attitude factors. The importance assigned to family, or conversely, to paid work, for example, are often found to vary by education or social class. These may affect the meanings given to housework, and thus the willingness to participate in it. In Ross (1987) and Pittman \& Blanchard (1996) it was found that education played a role in the household division of labor irrespective of sex-role attitudes. Twiggs et al. (1999) have argued that it may be more informative to look at household chores separately, since participation in them and the characteristics of those who participate in them may be different depending on how sex-typed a task is, similar to segregation in the labor market. They found that normative, or non-rational factors, such as attitudes and education, determined husbands' participation in different household chores more than practical factors. Educational level was significant only in washing the dishes, which was the least sex-segregated task. This may indicate that education affects which men are more likely to cross the boundary to participate at all.

The present study will investigate the division of housework and its determinants among Finnish dual-earner couples. First, on the basis of relative resources and time availability approaches, the study will examine to what extent selected rational or pragmatic 
factors are able to explain the variation in the participation in household labor in the Finnish data. The second aim of this article is to find whether education has an independent effect on the division of work when other variables, including factors measuring gender role attitudes, are controlled for. It is hypothesized that educational level will affect both men's and women's participation, with a higher educational level implying a more equal division. Since a more equal distribution of housework between partners can be achieved by men increasing their contribution or women decreasing theirs, or both, the models will be tested for both sexes separately. Another likely hypothesis is that the more equal distribution of tasks is solely a result of more educated women devoting less time to housework.

The third question to be addressed in this article is more related to methodological issues. Research on household labor has used both absolute time use data and relative measures. Contradictory results in the factors affecting the division may be partly explained by different measurement techniques of the dependent variable. Since in the survey the division of housework was inquired both with absolute time expenditure and direct questions concerning the relative division of tasks, it is possible to analyze these separately. Thus, the article examine whether the results from the analysis of absolute time use will be similar to those from the analysis of relative division. If the findings are inconsistent, more attention needs to be directed at the measurement technique and its effect on the results.

\section{Data and method}

The analysis is based on data collected by a postal survey conducted in 1998. In the survey, 2,500 persons aged 25 to 50 and living in households of two or more people were asked to report their time use, relative distribution of household tasks as well as their attitudes and opinions about gender roles, values concerning family and work, and problems related to the reconciliation of work and family. The questionnaire included questions about the employment and educational background of both the respondent and his/her partner. The overall response rate was 57 percent. Generally, women, older persons, married people, and those with a higher vocational education were somewhat over-represented in the data. In this analysis, a subsample of married or cohabiting persons living in dual-earner couples $(\mathrm{N}=993)$ is used. Table 1 presents a summary of some background variables and variables used in the analysis from this subsample. "Dual-earner" is here understood to mean that both partners are currently working. Generally, women with a child less than one year of age were excluded from the subsample, since in most cases the mother was still on maternity/parental leave and thus currently not working. Due to error in the questionnaire, there were more missing data in the question on education, and consequently, the size of the subsample is lower there. 
Table 1. Background characteristics: married or cohabiting persons from dual-earner couples $(\mathrm{N}=993)$

Age group

$45-50$

40-44

35-39

30-34

25-29

$\begin{array}{rrrrr}\begin{array}{c}\text { Men } \\ \text { Number }\end{array} & \% & \begin{array}{c}\text { Women } \\ \text { Number }\end{array} & \% & \text { Total } \\ & & & & \\ 104 & 25.8 & 162 & 30.6 & 266 \\ 87 & 21.6 & 130 & 24.5 & 217 \\ 74 & 18.4 & 94 & 17.7 & 168 \\ 67 & 16.6 & 79 & 14.9 & 146 \\ 71 & 17.6 & 65 & 12.3 & 136 \\ 403 & 100.0 & 530 & 100.0 & 933 \\ & & & & \\ 171 & 50.9 & 172 & 42.5 & 343 \\ 107 & 31.8 & 141 & 34.8 & 248 \\ 58 & 17.3 & 92 & 22.7 & 103 \\ 336 & 100.0 & 405 & 100.0 & 694\end{array}$

Respondent's earnings as \% of family income

Less than 40 percent of family income 40-60 percent of family income

Over 60 percent of family income

$\begin{array}{rrrrr}10 & 2.7 & 95 & 20.6 & 105 \\ 202 & 55.0 & 321 & 69.6 & 523 \\ 155 & 42.2 & 45 & 9.8 & 200 \\ 367 & 99.9 & 461 & 100.0 & 828\end{array}$

Number of children under 10

$1-2$

$3+$

$\begin{array}{rrrrr}193 & 47.9 & 324 & 61.1 & 517 \\ 188 & 46.7 & 190 & 35.8 & 378 \\ 22 & 5.5 & 16 & 3.0 & 38 \\ 403 & 100.1 & 530 & 99.9 & 933\end{array}$

\section{Working hours}

Less than $35 \mathrm{~h} /$ week

35-45 h/week

Over $45 \mathrm{~h} /$ week

$\begin{array}{rrrrr}20 & 5.1 & 90 & 17.2 & 110 \\ 315 & 79.7 & 401 & 76.8 & 716 \\ 60 & 15.2 & 31 & 5.9 & 91 \\ 395 & 100.0 & 522 & 99.9 & 917 \\ \text { (mean) } & & \text { (mean) } & & \text { (mean) } \\ 3.52 & & 3.42 & & 3.47 \\ & & & & \\ 2.47 & & 2.01 & & 2.21\end{array}$

\section{Attitude factors}

Woman's role equals family role

( $1=$ agree; $5=$ disagree)

Men should increase their

participation at home $(1=$ agree;

$5=$ disagree)

Participation in housework will be studied by using analysis of covariance, ANCOVA (of SPSS 10.0). It examines mean scores and their deviation from the overall mean of groups, adjusted for independent variables. Analysis of covariance, and related multiple classification analysis, will provide tests of significance, and predicted and adjusted means and deviations from the overall mean in absolute time use and relative distribution of tasks for categories of independent factors, as well as coefficients and tests of significance for covariates. 


\section{Measurement of dependent and independent variables}

\section{Dependent variable}

The dependent variable, division of household labor, is measured by using absolute time expenditure in certain tasks, and by using self-assessments of relative division of labor between partners. For the purpose of this article, I focus on the time spent on and the division of five typical household task, namely preparing meals, laying the table and washing dishes, doing laundry and ironing, cleaning the house, and shopping. These tasks are often described as feminine since in most cases women still perform the majority of them. As they are also time intensive and time restrictive in the sense that they have to be done daily or regularly, changes in the distribution of these tasks have apparent effects on the lives of family members. It is also clear that a marked change in the allocation of these traditionally feminine tasks implies changes in the roles of men and women in the family.

Respondents were asked to report their time use, in hours and minutes, in a number of activities during a typical working day and on weekends. A weekly time expenditure in the five household tasks was calculated by summing up the hours spent on a working day (multiplied by 5) and during the weekend. Daily time use turned out to be a rather demanding question and resulted in some missing data, especially in reporting the time use on weekends. Men seemed to suffer from this underreporting more than women, and estimates of hours spent in household tasks may thus be slightly too low among men. In the preliminary analysis, it was found that a clearly larger proportion among the lowest educated men had reported zero hours for the time spent on all nine household tasks specified in the questionnaire. When these were treated as missing data, and relevant cases excluded from the analysis, the results did not change markedly. Comparison of self-reported estimates from surveys and time use diaries has shown, on the other hand, that the reported time spent on housework is higher in the surveys than in time diary data, especially with more undefined or abstract tasks or tasks occurring frequently (Niemi 1993; Marini \& Shelton 1993). Naturally, the problems related to survey data on time use are present in this study as well.

Division of labor is also examined by using a relative measure. Respondents were asked to indicate the relative share of each family member and other persons in completing certain tasks. Again, I will focus on the division of labor between men and women in the five aforementioned tasks. Respondents' relative share is calculated as a ratio of her/his own share to the combined share. Although it was possible to indicate whether other family members or other persons participated in the tasks, in most cases the tasks were done totally or mostly by partners themselves. Children participated on average 
only a little. Other persons besides family members participated in these five tasks only very seldom or not at all. Since this is a subjective estimation of the relative division of labor between partners, it is not affected by the actual hours families spend doing these tasks. Thus, differences between families in their preferences and skills in doing household tasks, and ability to buy services outside the family, are controlled for. In addition, the relative measure provides information on the division of work between 'real partners'. A survey with individuals as respondents only provides absolute time use data of this individual, not of his/her partner. Proportional time spent on household activities can then be measured only by comparing mean hours men spent on a certain task to mean hours of women.

A relative measure of participation in housework will provide information about how partners perceive this division. Subjective estimates of relative division are perhaps more prone to overestimation of one's own share than seemingly neutral estimates of absolute time use. Assessments of the reliability of relative measures are scarce. In a study using both a time diary and relative measures, a correlation of 0.34 to 0.37 between a person's self-estimates and data from the time diary was found (Layte 1999). Among working couples, the correlation was 0.45 . The same study reported a correlation of 0.61 ( 0.77 among working couples) between female and male partners' estimates. When the relative division of tasks between partners was compared between female and male respondents in our data, it was found that both groups tended to exaggerate their own share at the expense of the other party. Differences between men's and women's accounts varied around 5 percentage points. There is no reason to expect that this overestimation varies systematically between different groups, and respondents' own accounts of their share are used to measure the division of labor in the household.

\section{Independent variables}

Educational level

Vocational education. The respondent's and his/her partner's educational levels were classified into three categories. No vocational education, vocational school, or vocational courses were combined into one category. The other two categories were vocational institute and university degree. In general, the three categories refer also to the length of vocational education. Vocational school lasts on average 2-3 years, vocational institutes about 4 years, and university studies about 5-7 years, or even longer. To test the hypothesis that relative education has an effect upon the division of housework, a variable with three categories (lower, the same, higher educational level than the partner's) was created. Also, a four-category variable was created (neither, either or both partners having at least vocational institute level education) in order to examine whether the effect of respondents' education would differ depending on their partner's education. 
Other independent variables

Earnings. Relative earnings are measured as the ratio of a respondent's earnings (measured in Finnish marks/month) to family earnings (both partners' earnings combined). It is expected, that with higher relative resources, e.g. higher relative earnings, the partner in question will be able to negotiate a lower share of household tasks.

Number of children under 10 years of age. Number of small children in the family is used to measure the demand factor of housework. According to the time availability approach, increasing the number of small children will increase the participation in household duties.

Weekly working time. Respondents' weekly working time measures the supply factor. Weekly working time is measured in minutes. It is expected that increased working time will decrease possibilities to participate at home.

Age group. Although measured by year of birth, this variable will be used as a categorical variable in the models. In the preliminary descriptive analysis it was found that age group, or year of birth, had a curvilinear effect upon housework. Age group will measure cohort effect, that is, the assumption that younger cohorts devote less time to housework than older cohorts.

\section{Attitude factors}

Respondents' gender role ideologies were measured with several attitude questions which were then factor analyzed. Two gender role factors, which in the preliminary analysis turned out to have significant effects upon the division of household labor, will be used in the analysis.

Woman's role equals family role. This orientation was created from five items ("Very career-oriented men should not have a working wife", "Paid work means more to a man than to a woman", "Raising children is, in general, more rewarding to a woman than having a career", "Women are not as committed to their work as men", "Women are less suited to the competition in working life than men"), with the eigenvalue 2.05, and Cronbach's alpha .64.

Men should increase their participation at home. This was created from two items ("Men should take a daily active role in all aspects of their children's upbringing", "Men should do half the housework"), with the eigenvalue 1.98 and Cronbach's alpha 48 .

It is expected that person with more traditional attitudes (agreeing with 'woman's role equals family role', or disagreeing with 'men should increase their participation at home') will also behave along traditional lines, e.g. men devote less time to housework and women more.

\section{Division of work between men and women}

As expected, women spent more time on household tasks than men. Since the difference between average hours in employment was small (48.5 hours/week among men, 
44.5 hours/week among women) women's total weekly workload (when paid work and all housework, except child care, are combined) exceeded that of men by almost eight hours. When the time used for the five household tasks is compared between men and women (Table 2), women spent 2.5 times as many hours on the five household tasks as men did ( 20.4 hours versus 8.2 hours). The most time-consuming task among all women was meal preparation, while men spent the most time on meal preparation and shopping. Men with higher vocational education tended to spend a little more time on housework than men with no vocational education or with education from a vocational school. There seemed to be an increase in the time spent on every task, suggesting that if more educated men increase their contribution to housework, they are likely to do all kinds of tasks. Education has an opposite effect on women: those with a higher education tended to spend less time on housework. The decrease was most visible in meal preparation.

Table 2. Absolute time spent on five household tasks (hours per week)

\begin{tabular}{|c|c|c|c|c|}
\hline & & & & \\
\hline & $\begin{array}{l}\text { No vocational } \\
\text { education, voc. } \\
\text { school }\end{array}$ & $\begin{array}{l}\text { Vocational } \\
\text { institute }\end{array}$ & $\begin{array}{l}\text { University } \\
\text { degree }\end{array}$ & All \\
\hline Preparing meals & 2.5 & 2.8 & 2.6 & 2.6 \\
\hline Washing dishes & 1.1 & 1.2 & 1.5 & 1.2 \\
\hline Laundry, ironing & 0.6 & 0.8 & 1.0 & 0.7 \\
\hline Cleaning & 1.4 & 1.5 & 1.8 & 1.5 \\
\hline Shopping & 2.0 & 2.4 & 2.1 & 2.1 \\
\hline Household tasks, all five & 7.6 & 8.7 & 9.0 & 8.2 \\
\hline & & Wo & & \\
\hline & $\begin{array}{c}\text { No vocational } \\
\text { education, voc. } \\
\text { school }\end{array}$ & $\begin{array}{l}\text { Vocational } \\
\text { institute }\end{array}$ & $\begin{array}{l}\text { University } \\
\text { degree }\end{array}$ & All \\
\hline Preparing meals & 8.3 & 6.6 & 6.6 & 7.3 \\
\hline Washing dishes & 2.6 & 2.4 & 2.6 & 2.5 \\
\hline Laundry, ironing & 3.6 & 3.7 & 3.0 & 3.5 \\
\hline Cleaning & 4.2 & 3.9 & 3.9 & 4.0 \\
\hline Shopping & 3.1 & 3.0 & 2.8 & 3.0 \\
\hline Household tasks, all five & 21.9 & 19.6 & 18.9 & 20.4 \\
\hline Time use on housework & 0.35 & 0.44 & 0.48 & 0.40 \\
\hline
\end{tabular}

The gendered division of housework is reproduced in the accounts of the relative division of tasks (Table 3). Both men and women with a higher education report a more equal distribution of tasks. Again, men with higher education tended to participate more in all tasks. In the most gender-specific task, doing the laundry, more than 30 percent of men with lower education did not participate at all, while among men with a university level education, the proportion of persons who did not participate at all was about 10 percent. Education had a similar effect in meal preparation, though not as clear. In the 
other tasks, the proportions of those who did not participate at all varied only a little between education groups (table not presented here).

Table 3. Relative distribution of tasks (proportion based on own account)

\begin{tabular}{|c|c|c|c|c|}
\hline & \multicolumn{4}{|c|}{ Men } \\
\hline & $\begin{array}{l}\text { No vocational } \\
\text { education, voc. } \\
\text { school }\end{array}$ & $\begin{array}{l}\text { Vocational } \\
\text { institute }\end{array}$ & University degree & All \\
\hline Preparing meals & 21.3 & 27.5 & 26.6 & 24.2 \\
\hline Washing dishes & 26.4 & 27.9 & 37.0 & 28.7 \\
\hline Laundry, ironing & 10.0 & 16.0 & 26.4 & 14.7 \\
\hline Cleaning & 25.3 & 27.2 & 44.1 & 29.2 \\
\hline Shopping & 36.9 & 40.9 & 42.4 & 39.1 \\
\hline \multirow[t]{3}{*}{ Household tasks, all five } & 25.1 & 29.9 & 38.4 & 29.0 \\
\hline & \multicolumn{4}{|c|}{ Women } \\
\hline & $\begin{array}{c}\text { No vocational } \\
\text { education, voc. } \\
\text { school }\end{array}$ & $\begin{array}{l}\text { Vocational } \\
\text { institute }\end{array}$ & University degree & All \\
\hline Preparing meals & 74.9 & 71.4 & 59.8 & 70.3 \\
\hline Washing dishes & 69.3 & 63.6 & 59.8 & 65.2 \\
\hline Laundry, ironing & 86.7 & 79.1 & 75.1 & 81.4 \\
\hline Cleaning & 72.9 & 64.0 & 61.5 & 67.2 \\
\hline Shopping & 68.8 & 60.7 & 53.3 & 62.5 \\
\hline Household tasks, all five & 78.7 & 73.3 & 67.0 & 74.1 \\
\hline
\end{tabular}

The two measures correlated significantly among both men and women $\left(\mathrm{r}=.418^{* *}\right.$, $\left.\mathrm{r}=.249^{* *}\right)$, e.g. persons who reported more time spent in absolute hours on household tasks also indicated a greater relative share for themselves. Correlation was higher among men than women. It is possible that women tend to overestimate their share in these feminine tasks and thus the association between actual time used for these tasks and the reported relative share is lower among them. According to Niemi (1984), social desirability, or the idea that certain tasks belong to women, causes women with more traditional attitudes towards gender roles to overestimate their role in completing these chores. This social desirability did not seem to cause underestimation among men in her study.

\section{Analysis}

Tables 4 and 5 show the results of analysis of variance for two dependent variables. In Table 4 the dependent variable is the absolute time spent on five household tasks, in Table 5, it is the relative division of the tasks. The tables present only one model, separately for men and women. In addition, two other models with variables measuring relative educational level were tested. More descriptive tables of the mean time spent 
on housework and relative division by chosen variables are included in the appendix in Tables 1 and 2 .

In Table 4 (page 54) it can be seen that only two of the variables chosen for the analysis have a significant effect upon the variation in the number of hours men devote to housework, but that they are clearly better predictors of women's contribution. Weekly working time has a predicted relationship with the time used for household tasks among men, but not among women: when employed time increases, men allocate less time to housework (the coefficients show the average decrease, or increase, in minutes, in the time used for housework when the covariate, here weekly working time, increases by one unit). The other variable measuring situational factors, or time availability/demands for housework, the number of children under 10 years of age is not a significant determinant of men's time use on housework. However, it clearly affects women's time use, thus giving support to the notion that children increase especially women's workload in the family (every additional child increases women's housework by approximately 99 minutes). Contrary to the relative resources theory, relative earnings do not affect the number of hours spent on housework.

Of the two variables describing attitudes towards gender roles, the attitude towards men's role in a family has a significant effect upon housework among men. Men who have more traditional attitudes and who believe that men's role in the family should not be increased are also less likely to devote more time to housework. In accordance, women who feel that women's role does not only equal family role, used less time on household tasks. Only the attitude factor measuring normative expectations towards the respondents' own sex was a significant determinant of the number of hours devoted to housework. Thus, the participation of men in housework is clearly associated with men's ideas of their role in the family. Even if Finns seem to support equality and are fairly modern in their sex-role attitudes (see for example Ervasti 2000 and Melkas 1998), attitudes towards the role of the opposite sex are not reflected in their behavior, at least when it comes to the division of routine household tasks. Since this is a crosssectional study, it is not possible to determine whether behavior follows the attitude or the reverse. The cohort effect, or the assumption that younger cohorts spent less time doing housework than older cohorts was significant among women, but not among men. In fact, the highest number of hours used for housework was found among the second oldest (among women), or in the middle age groups (among men).

The level of vocational education failed to significantly affect housework among men, when other variables were controlled for. Although higher educational levels seemed to be positively associated with time used for housework (men with a vocational school education spent an average of 7.6 hours per week on housework while men with a university degree spent an average of 8.8 hours, when the effects of other factors were controlled for), the variation within educational groups was greater than between the 
Table 4. An ANCOVA model of the absolute time expenditure (time is measured in minutes/week) on five household tasks, with selected independent variables

Note: In the factors age group and vocational education, average minutes of housework are transformed into hours to make it easier to understand the results. In the grand mean and covariates, average time/ change in the time use is measured in minutes/week.

\begin{tabular}{|c|c|c|c|c|c|}
\hline & Women & & & Men & \\
\hline Grand mean (minutes/week) & $\begin{array}{l}\text { B-Coeff. } \\
1230.93\end{array}$ & & & $\begin{array}{l}\text { B-Coeff. } \\
486.05\end{array}$ & \\
\hline Relative earnings & -1.621 & & & -.272 & \\
\hline Number of children under 10 & $98.713^{\star *}$ & & & 40.497 & \\
\hline Weekly working time & 2.801E-02 & & & $-.124\left(^{*}\right)$ & \\
\hline $\begin{array}{l}\text { Woman's role equals family role } \\
(1=\text { agree })\end{array}$ & $-161.037^{\star \star \star}$ & & & -15.444 & \\
\hline $\begin{array}{l}\text { Men should increase their } \\
\text { participation at home ( } 1=\text { agree) }\end{array}$ & 27.851 & & & $-44.566\left(^{*}\right)$ & \\
\hline $\begin{array}{l}\text { Age group (Sig.) } \\
\text { (1) } 45-50(N=94) \\
\text { (2) } 40-44(N=95) \\
\text { (3) } 35-39(\mathrm{~N}=67) \\
\text { (4) } 30-34(\mathrm{~N}=59) \\
\text { (5) } 25-29(\mathrm{~N}=47)\end{array}$ & $\begin{array}{l}\text { Unadjusted } \\
\text { means } \\
\left({ }^{* * *}\right) \\
20.0 \\
23.7 \\
20.4 \\
19.5 \\
16.6 \\
\text { Eta } .217\end{array}$ & $\begin{array}{l}\text { Adjusted } \\
\text { means } \\
\\
20.7 \\
24.1 \\
19.1 \\
18.6 \\
17.3 \\
\text { Beta .235 }\end{array}$ & $\begin{array}{l}(N=74) \\
(N=59) \\
(N=62) \\
(N=51) \\
(N=55)\end{array}$ & $\begin{array}{l}\text { Unadjuste } \\
\text { d means } \\
(-) \\
6.6 \\
8.9 \\
9.3 \\
8.6 \\
7.4 \\
\text { Eta } .165\end{array}$ & $\begin{array}{l}\text { Adjusted } \\
\text { means } \\
6.8 \\
8.7 \\
9.3 \\
8.6 \\
7.4 \\
\text { Beta .154 }\end{array}$ \\
\hline $\begin{array}{l}\text { Vocational education (Sig.) } \\
\text { (1) No voc.education, vocational } \\
\text { school }(N=155) \\
\text { (2) Vocational institute }(N=125) \\
\text { (3) University degree }(N=82)\end{array}$ & $\begin{array}{l}\left({ }^{*}\right) \\
22.2 \\
19.4 \\
19.1 \\
\text { Eta. } 141\end{array}$ & $\begin{array}{l}22.1 \\
19.7 \\
18.9 \\
\text { Beta.136 }\end{array}$ & $\begin{array}{l}(\mathrm{N}=148) \\
(\mathrm{N}=99) \\
(\mathrm{N}=54)\end{array}$ & $\begin{array}{l}(-) \\
7.5 \\
\\
8.5 \\
9.0 \\
\text { Eta } .098\end{array}$ & $\begin{array}{l}7.6 \\
8.5 \\
8.8 \\
\text { Beta .083 }\end{array}$ \\
\hline $\begin{array}{c}\text { Model F } \\
\text { Sig. } \\
\mathrm{R}^{2}\end{array}$ & $\begin{array}{r}4.725 \\
.000 \\
.129\end{array}$ & & & $\begin{array}{r}1.968 \\
.031 \\
.070\end{array}$ & \\
\hline
\end{tabular}

Method: ANCOVA, experimental with covariates entered first

groups. On the other hand, education did affect women's contribution in the predicted way. Women with a higher vocational education spent significantly less time on housework than women with a lower education. No significant interaction effect between factors was found in the data. This means that the effect of education is similar in all age groups, and that it plays a role among women also in the younger cohorts in determining the amount of time they spend on housework. 
When we turn to relative division of housework, we get a somewhat different picture of the factors affecting the division (Table 5, page 56). Of the covariates, only attitude factors have a significant effect on the relative division among both men and women. The number of children, relative earnings, or weekly working time do not affect the way respondents perceive their division of labor. The cohort, or age group factor, does not have a significant effect upon the relative division either.

Attitude factors are very important in explaining the relative division. Among women, both attitude factors had a predicted effect upon the division. Women with less traditional attitudes about women's role did a smaller share of the housework, and women with more traditional attitudes about men's role in the family increased their share. Since the negotiation over the division of labor at home involves both partners, it is also possible that women who hold more traditional attitudes about men's role in the family and in child care may not be willing to increase men's role in certain tasks. Among men, only the factor measuring attitudes towards men's role had a significant and predicted effect (more traditional men had a reduced share).

Even with the inclusion of attitude factors, vocational education still has predictive power on the relative division both among men and women. Among both sexes, increasing education implied a more equal distribution of tasks. On the basis of the analysis of absolute time use, the more equal distribution of housework in the households with educated women seems to be the result of these women doing less housework. In a Finnish study on gender role attitudes (Ervasti 2000) it was found that perceptions of inequality between the sexes in the family and in working life diminished with education, e.g. men and women with lower education were more conscious about gender inequalities especially in the family than persons with higher education, thus giving support to the findings from this study.

Normative factors appeared to be better predictors of the perceived division of housework than pragmatic or rational factors (working time, number of children, or earnings). Although attitude factors and education did have a significant effect on absolute time use, and thus may contribute to more equal distribution of work, it is possible that they are indicators of a 'family myth'. According to Hochschild (1989), family myth is created when there exists a discrepancy between the actual division of work between partners and the expected, or preferred division. In her study she found that some couples with non-traditional attitudes about gender roles and division of housework presented, or perceived their division as more equal than it actually was. Persons with higher education and more non-traditional attitudes are more likely to value equality highly and thus report the division of tasks as being more equal to confirm their ideals of the familial division of work. It is also possible that even a small increase in men's participation may be judged as substantial by their partners, depending on the wives' initial ideas and norms about gender behavior. Another possible explanation is that 
Table 5. An ANCOVA model of the relative division of five household tasks, with selected independent variables



husbands' participation in other household tasks, or in child care, is understood to compensate for lack of participation in the routine chores.

To test the assumption that the partner with a higher level of education would be able to reduce his/her participation in housework, a model with relative educational level was analyzed. However, it did not have any significant effect upon the number of hours spent on housework, nor on the relative division of housework. Relative resources theory and the hypothesis of the effect of power differentials upon the division of 
housework thus failed to be supported by this data. Neither relative earnings nor relative educational level had a significant effect upon participation in housework.

In the preliminary analysis it was found that wives' vocational education explained more of the variation in the number of hours men used for housework than men's own educational level. Thus, a model which included a variable measuring both partners' vocational education was analyzed to test whether the effect of the respondents' own education depended on their partner's education. In other words, are women with a higher vocational education able to invoke more help from their husbands, measured both by absolute number of hours or by relative division, irrespective of their husbands' education? Table 6 (page 58) seems to provide at least some evidence for this. In the table, only the unadjusted and adjusted means for the factor measuring both partners' education are presented (the effects of control variables did not change markedly from those presented in Tables 4 and 5). The relative division was most equal (the wives' share was smallest and the husbands' greatest) in the two categories in which the wife had at least vocational institute education. Contrary to the power perspective, the husbands' share actually increased (and the wives' decreased) when their level of education was higher than that of their wives (from $25.5 \%$ to $30.3 \%$ ), and was the highest $(33.1 \%)$ in the category where both partners had a higher education. However, the effect of the variable measuring both partners' education on the relative division of housework did not get statistical support from absolute time use. In other words, although the time use among men supported the notions made on the basis of the relative division, the effect failed to be statistically significant (it had an almost significant effect $(\mathrm{p}=0.055)$ upon women's time use).

The models analyzed in this article were able to explain only 7 to 13 percent of the variation in the number of hours used for housework. Selected variables predicted more women's time use than men's. In addition to attitude factors explaining the time spent on housework, the number of small children had a significant effect on women's work. On the other hand, men's contribution was affected more by the supply factor than by other factors. Increased hours in employment reduced men's participation in housework. Vocational education had a predicted effect upon women's time use, but failed to have any significant effect on men's time use. Thus, the second assumption that education affects only women's behavior did get support from this data, even with the inclusion of a sex-role factor. It is possible that educational level captures life-style preferences or values which were not measured by the attitude factors used in these models.

The variables chosen for the analysis were able to explain more of the variance in the relative division of tasks (14 and 16 percent). However, only the normative factors (attitudes and education) had a significant effect upon the perceived division, and, perhaps somewhat surprisingly, none of the rational or pragmatic factors did. Since the 
Table 6. The effect of both partners' education level on the number of hours spent on five household tasks and on the relative division of tasks

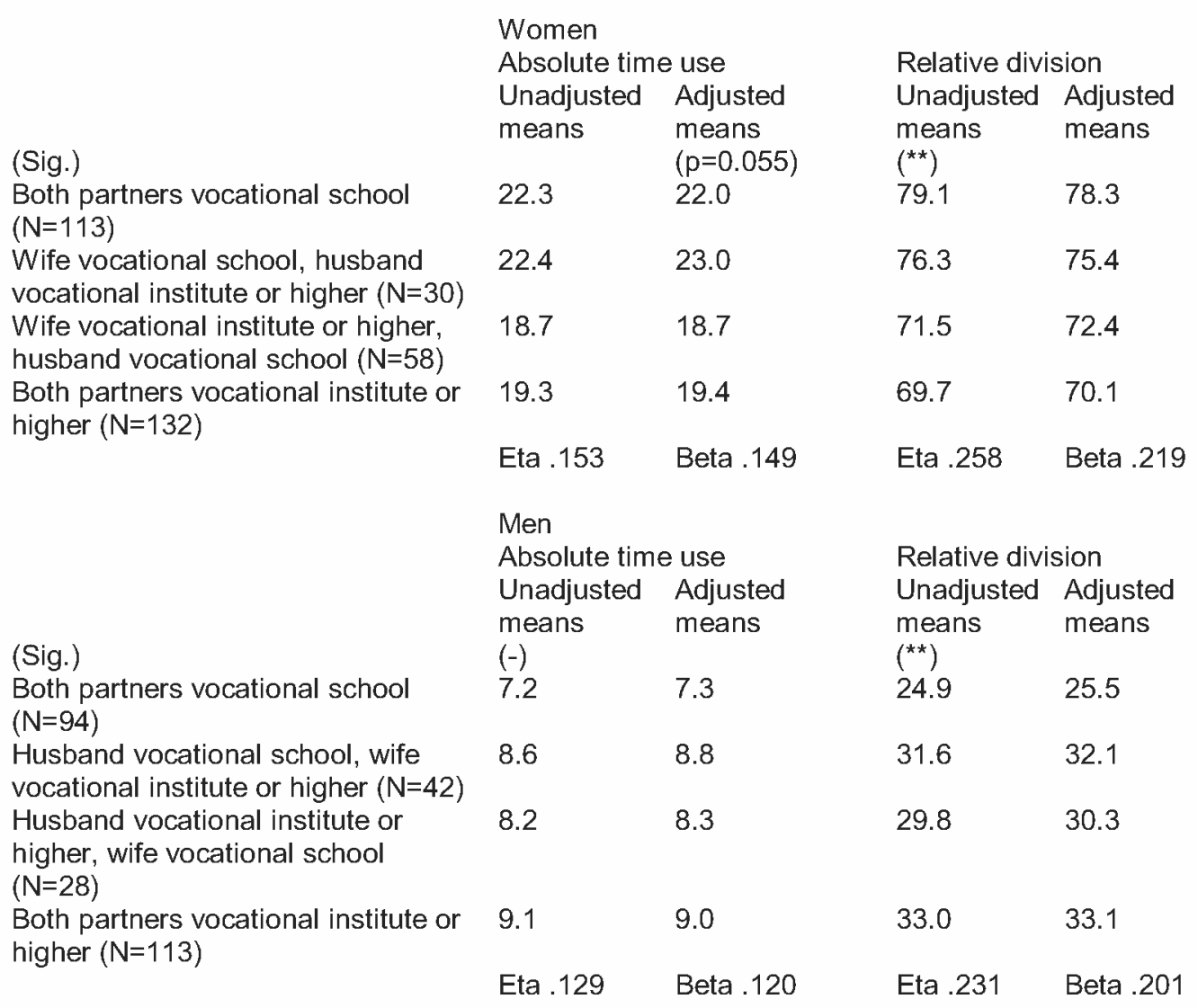

two analyses yielded somewhat different results, it is possible that some of the inconsistencies between findings from different studies may thus be attributed to different measurement techniques of the dependent variable.

\section{Discussion}

The gender division of household labor has proven to be very resistant to change. Findings in this article are similar to those reported by Niemi in her article (1984) based on time budget study conducted in Finland in 1979. Education and age cohort are only able to explain women's participation in housework, but not men's. The effect of age seems to capture more a life course effect than a cohort effect. Although it may be that younger generations are socialized into reduced standards of housekeeping or that they are more willing to use new technologies or buy outside services, and that it can be 
expected that in the future women's time use on housework will still decrease, the similar findings of the time spent on housework in age groups in this article and in the 1979 data seem to suggest that life course events are more important in determining women's time use than the birth cohort. Birth of a child, and number of small children in the family increase both partners' contributions, but the increase is more marked among women. In studies from other countries it has been found that marriage or union formation alone marks a difference in the time use and the division of household tasks: women's contributions increase and men's decrease (South \& Spitze 1994; Jacobs et al. 2000)

Although the available time, when it was measured as weekly working time, did not have any significant effect upon women's time use, it is possible that in a future analysis we need to refine the concept of available time. Partners' overlapping hours in employment, or shift working may be better predictors of both men's and women's participation in housework than simply the total time in employment, as already pointed out by Presser (1994). Increase of part-time work and flexible working hours may thus in the future have important effects in the familial division of both paid and unpaid work. It is also possible, that other commitments than paid work reduce the real available time. Some of these may be related to education, for example, the need to bring work from the work place to home, working extra hours, participating in other activities (meetings, social clubs, etc.) may be more common among educated persons, thus requiring more contributions at home from the partners.

In this article, division of work was examined by focusing on only five household tasks. It can be argued that inclusion of other tasks, such as child care, might have produced another picture. There is some evidence that gendered allocation of work at home is less accentuated in tasks related, for example, to child care. Indeed this was the case also with the Finnish data. The ratio of men's time use on child care to that of women's was 60-70 percent in households with children under 10, when their share of the time used on routine household tasks varied between 35 to 50 in the same households.

Since the normative factors turned out to have an impact on the division of work in the family both in the analysis of absolute time expenditure and relative division, it is evident that more research upon gender role attitudes and norms affecting the division of household chores is needed. Men in general seem to hold more traditional attitudes towards family and gender roles (Ervasti 2000; Melkas 1998), but since the majority of them feel that their role in the family should be increased, it is possible that not only the expectations towards men's role in the family but also their behavior can be expected to change gradually. The need to include attitude or normative factors in future studies is also implicitly supported by the findings that different factors affected men's and women's time use. Why, for example, do children affect women's time use, but not men's, or why does time in employment decrease men's participation, but not women's? The fact 
that wives' education affected husbands' time use more than the husbands' own educational level, and that women with more non-traditional ideas about men's role in families did a lower share of housework seems to suggest that wives' attitudes, along with their work commitments, may be important factors in explaining the husbands' participation.

The Finnish study was part of a European project entitled 'Policies and division of paid and unpaid work in the family' in which a number of European countries agreed to conduct a survey along similar lines. In the future, it may be hoped that the possibility to use comparable data from countries with a different cultural and political context will provide more insights into the factors that determine participation in housework.

\section{References}

Barnett, Rosalind C. and Grace K. Baruch. 1987. Determinants of Fathers' Participation in Family Work. Journal of Marriage and the Family 49:29-40.

Becker, Gary. 1993. A Treatise on the Family. Enlarged edition. Harvard University Press, Cambridge, Massachusetts.

Bergen, E. 1991. The Economic Context of Labor Allocation. Journal of Family Issues $12: 140-157$.

Berk, Sarah Fenstermaker. 1985. The gender factory: the apportionment of work in American households. Plenum Press, New York.

Blair, SL. 1993. Employment, Family, and Perceptions of Marital Quality Among Husbands and Wives. Journal of Family Issues 14:189-212.

Blair, SL \& Lichter, DT. 1991. Measuring the Division of Household Labor: Gender Segregation of Housework among American Couples. Journal of Family Issues 12:91113.

Blood, Robert O. \& Wolfe, Donald M. 1960. Husbands and Wives. The Dynamics of Married Living. Free Press, New York.

Brayfield, April A. 1992. Employment Resources and Housework in Canada. Journal of Marriage and the Family 54:19-30.

Brines, Julie. 1994. Economic Dependency, Gender, and the Division of Labor at Home. American Journal of Sociology 100:652-688.

Coltrane, Scott. 2000. Research on Household Labor: Modeling and Measuring the Social Embeddedness of Routine Family Work. Journal of Marriage and the Family 62:12081233.

Coverman, Shelley. 1985. Explaining Husbands' Participation in Domestic Labor. Sociological quarterly 26:81-97.

Ervasti, Heikki. 2000. Suomalaisten perhe- ja sukupuolirooleja koskevat asenteet. (Attitudes towards family and gender roles in Finland). In: Eriarvoisuutta paikantamassa, edited by Veli-Matti Ritakallio, Heikki Ervasti, Katja Forssén and Kaarina Nurmi, pp. 54-76. Turku: Turun yliopiston sosiaalipolitiikan laitos, Sosiaalipoliittinen yhdistys ry.

Farkas, George. 1976. Education, Wage Rates, and the Division of Labor Between Husband and Wife. Journal of Marriage and the Family 38:473-483.

Ferree, Myra Marx. 1990. Beyond Separate Spheres: Feminism and Family Research. Journal of Marriage and the Family 52:866-844. 
Ferree, Myra Marx. 1991. The gender division of labor in two-earner marriages: Dimensions of variability and change. Journal of Family Issues 12:158-180.

Haavio-Mannila, Elina, Riitta Jallinoja and Harriet Strandell. 1984. Perhe, työ ja tunteet. WSOY, Helsinki.

Hochschild, Arlie, with Machung, Anne. 1989. The Second Shift. Avon, New York.

Jacobs, Menno. 2000. Unpublished presentation in the meeting of Network on Policies and the Division of Paid and Unpaid Labor in Families, in Rome 28.-30.9.2000. (Data was obtained from surveys performed by the participating countries).

Kamo, Yoshinori. 1988. Determinants of Household Division of Labor. Resources, Power, and Ideology. Journal of Family Issues 9:177-200.

Kluwer, Esther S., José A. M. Heesink and Evert Van de Vliert. 1996. Marital Conflict About the Division of Household Labor and Paid Work. Journal of Marriage and the Family 58:958-969.

Künzler, Jan. 1996. Families' Division of Labor. Influential factors. Unpublished paper for the Network on Policies and the Division of Paid and Unpaid Labor in Families.

Layte, Richard. 1999. Divided Time. Gender, paid employment and domestic labour: Ashgate, Aldershot (UK).

Marini, Margaret Mooney and Beth Anne Shelton. 1993. Measuring Household Work: Recent Experience in the United States. Social Science Research 22:361-382.

Melkas, Tuula. 1998. Tasa-arvobarometri 1998 (Equality barometer 1998). Elinolot 1998:1, Sukupuolten tasa-arvo. Tasa-arvoasiain neuvottelukunta \& Tilastokeskus, Helsinki.

Miettinen, Anneli. 1997. Work and Family. Series E, Working Papers. Väestöliitto, Väestöntutkimuslaitos, Helsinki.

Niemi, Iiris. 1984. Kotityön harhat (The illusions of housework). Sosiologia 3:211-218.

Niemi, Iiris. 1993. Systematic Error in Behavioural Measurement: Comparing Results from Interview and Time Budget Studies. Social Indicators Research 30:229-244.

Niemi, Iiris and Hannu Pääkkönen. 1989. Ajankäytön muutokset 1980-luvulla (Changes in time use in the 1980s). Statistics Finland, Studies 153. Helsinki: Statistics Finland.

Piña, Darlene L. and Vern L. Bengtson. 1993. The Division of Household Labor and Wives' Happiness: Ideology, Employment, and Perceptions of Support. Journal of Marriage and the Family 55:901-912.

Pittman, Joe F. and David Blanchard. 1996. The Effects of Work History and Timing of Marriage on the Division of Household Labor. A Life-course Perspective. Journal of Marriage and the Family 58:78-90.

Presser, Harriet. 1994. Employment Schedules Among Dual-Earner Spouses and the Division of Household Labor by Gender. American Sociological Review 59:348-364.

Reuna, Veera. 1998. Perhebarometri 1998 (Family barometer 1998). Working Papers E 4/ 1998. Väestöliitto, Väestöntutkimuslaitos, Helsinki.

Rexroat, Cynthia and Constance Shehan. 1987. The Family Life Cycle and Spouses' Time in Housework. Journal of Marriage and the Family 49:737-750.

Ross, Catherine E. 1987. The Division of Labor at Home. Social Forces 65:816-833.

Shelton, Beth Anne and Daphne John. 1996. The Division of Household Labor. Annual Reviews in Sociology 22:299-322.

South, Scott J. and Glenna Spitze. 1994. Housework in Marital and Nonmarital Households. American Sociological Review 50:327-347.

Stafford, Rebecca, Elaine Backman and Pamela Dibona. 1977. The Division of Labor Among Cohabiting and Married Couples. Journal of Marriage and the Family 39:43-57.

Twiggs, Joan E., Julia McQuillan and Myra Marx Ferree. 1999. Meaning and Measurement: Reconceptualizing Measures of the Division of Household Labor. Journal of Marriage and the Family 61:712-724. 
Appendix

Table 1. Average time expenditure (in hours/week) on five household tasks by selected variables

\section{Respondent's relative earnings}

Less than 40 percent of family income

40-60 percent of family income

Over 60 percent of family income

\section{Weekly working time}

Less than $35 \mathrm{~h} /$ week (0-2099 $\mathrm{min}$ )

$35-38 \mathrm{~h} /$ week (2100-2280 $\mathrm{min})$

38.1-43 h/week (2281-2580 $\mathrm{min})$

Over 43 h/week (2581- min)

Number of children under 10 years

$$
\text { of age }
$$$$
0
$$$$
1
$$

2

$3+$

$\begin{array}{rrrr}\text { Men } & \text { N } & \text { Women } & \text { N } \\ 8.0 & 11 & 22.0 & 107 \\ 8.4 & 202 & 20.6 & 321 \\ 8.6 & 160 & 22.3 & 47\end{array}$

$\begin{array}{llll}9.9 & 20 & 22.0 & 90\end{array}$

$\begin{array}{llll}8.6 & 100 & 20.0 & 189\end{array}$

$\begin{array}{llll}9.1 & 200 & 20.6 & 202\end{array}$

$\begin{array}{lrrr}6.3 & 75 & 23.5 & 41\end{array}$

$\begin{array}{rrrr}8.3 & 193 & 20.3 & 324 \\ 8.9 & 97 & 21.2 & 121 \\ 8.2 & 91 & 23.7 & 69 \\ 9.3 & 22 & 20.9 & 16\end{array}$

Table 2. Relative division of household tasks (own report) by selected variables

\section{Respondent's relative earnings}

Less than 40 percent of family income

40-60 percent of family income

Over 60 percent of family income

\section{Weekly working time}

Less than $35 \mathrm{~h} /$ week (0-2099 $\mathrm{min}$ )

35-38 h/week (2100-2280 min)

38.1-43 h/week (2281-2580 min)

Over 43 h/week (2581- min)

\section{Number of children under 10 years}

\section{of age}

0

1

2

$3+$

$\begin{array}{rrrr}\text { Men } & \text { N } & \text { Women } & \text { N } \\ & & & \\ 29.1 & 11 & 78.6 & 105 \\ 30.4 & 200 & 72.6 & 316 \\ 27.9 & 158 & 74.0 & 46\end{array}$

32.4

32.4

28.7

23.7

20
99
198
74

77.2

72.3

$74.5 \quad 198$

$79.8 \quad 40$

$\begin{array}{rrrr}29.0 & 190 & 75.1 & 316 \\ 30.0 & 97 & 74.0 & 120 \\ 28.5 & 91 & 74.0 & 68 \\ 23.4 & 21 & 72.9 & 16\end{array}$

